\title{
Prefabricated Housing Business Strategy for Dummies
}

\author{
Yofangga Rayson*, Ningky Sasanti Munir \\ Sekolah Tinggi Manajemen PPM \\ Jakarta, Indonesia \\ *yofangga@gmail.com,nky@ppm-manajemen.ac.id
}

\begin{abstract}
Rapid technological developments have changed many things in the construction industry, particularly in the development methods. One technologies that gives a considerable influence in this industry is a prefabricated system, where the building components have been produced previously in the factory and transported to the construction site to be assembled. Woodlam Indonesia is a new company that produces prefabricated houses for middle to upper market segments. The problem is, the use of prefabricated systems for housing construction has not been widely known by people in Indonesia. Besides educating the people continuously, Woodlam Indonesia must have another way to survive in this prefabricated housing industry. Therefore, a business strategy is needed to clarify the goals and directions of the company's work in the future. The aim of this study is to analyze the business models that are being carried out by Woodlam Indonesia and recommend business strategies that should be implemented. The research method is descriptive cross sectional with case study approach in the company. The data collection techniques are by conducting interviews, observations, and literature studies. Based on the results of this study, several strategic plans were carried out for the next three years that was in line with PT. Woodlam Indonesia Abadi, namely "Quality of Life". Strategies to improve market penetration that will be carried out are (1) Using early adopter public figure to show the luxury of prefabricated houses; (2) Improving marketing tools by optimizing digital marketing; (3) promote sustainability in every marketing campaign used by Woodlam Indonesia.
\end{abstract}

Keywords-construction, prefabricated system, business strategy, business model

\section{INTRODUCTION}

In developing countries, the construction sector is an important part of Gross Domestic Product (GDP) and is one of the biggest contributors to economic growth [1]. According to first semester 2018 assessment held by Bank Indonesia [2], the contribution of the construction sector to national economic growth for $2011-2017$ was recorded at $0.64 \%$ per year with an increasing trend. In that period, the construction sector was the third highest contributor to Indonesia's economic growth, after the wholesale and retail trade processing sector, and repairs to cars \& motorcycles with an average contribution of $1.05 \%$ and $0.70 \%$ per year.

However, the magnitude of that contribution to national economic growth is apparently not always in line with the quality of housing felt by the community. According to Mostafa [3], the majority of people living in developing countries cannot afford to buy a qualified house. Housing contractors still operate traditionally with a primary focus on profits, not on the value obtained by users, so that people are forced to live in an environment with poor housing quality.

Government policies, the availability of skilled labor, and building material resources play an important role in the progress of the home construction industry. Some of the challenges that many contractors face in this industry are related to quality deficiencies and high housing production costs. To overcome this, several initiatives have been introduced, one of which is the prefabrication system [3].

Prefabrication is a method of development whose components (be it floor, wall, or roof) have been produced beforehand in the factory, and then assembled in the field [4]. With the prefabrication method, the development process can be carried out faster. In addition, because all components have been produced in factories that have a quality control system, the quality of building materials can be more accurate and precise [5]. According to Bell, there are five forms of prefabrication [6], consist of:

TABLE I. PREFABRICATED SYSTEM CATEGORIES

\begin{tabular}{|l|l|l|}
\hline $\begin{array}{c}\text { Prefab } \\
\text { level }\end{array}$ & \multicolumn{1}{|c|}{ Type } & \multicolumn{1}{c|}{ Definition } \\
\hline Low & Material & $\begin{array}{l}\text { Standard building materials that have not been } \\
\text { processed at all. Directly used in construction } \\
\text { (installed or assembled on site). }\end{array}$ \\
\hline Component & $\begin{array}{l}\text { Element that has been previously cut at the } \\
\text { factory Shaped precut components or } \\
\text { components ready to install such as doors, } \\
\text { windows, and sills. }\end{array}$ \\
\hline Panel & $\begin{array}{l}\text { Non-volumetric structural elements that can be } \\
\text { used to make spaces, such as Structural } \\
\text { Insulated Panels (SIPs), precast concrete panels, } \\
\text { and structural wood panels. }\end{array}$ \\
\hline High & Modular & $\begin{array}{l}\text { Three-dimensional structural units that have } \\
\text { been installed at the factory and transported to } \\
\text { the location to be combined with other units so } \\
\text { that they become a single dwelling. }\end{array}$ \\
\hline
\end{tabular}

Source: [6]

This prefabricated system has many advantages compared to conventional construction systems, for instance increasing speed, improving work health and safety, overcoming the shortage of skilled labor, minimizing waste and energy consumption, not depending on the weather, costs and time could be predicted accurately, and control the overall work so that it is possible to improve quality [7]. 
Based on research conducted by $\mathrm{Lu}$, construction using prefabricated components in the United States can reduce construction time, improve building quality, implement quality, and increase labor productivity [8]. Garrison and Tweedie also said that the time efficiency in prefabricated construction systems can reach $50-70 \%$ faster when compared to conventional construction systems [9].

Because of its rapid characteristics, the prefabricated system is gaining popularity as an ideal solution in the construction of mass housing and post-disaster housing. Homes with prefabricated systems are also increasingly being used because of their potential in providing sustainable buildings. Over the past few years, prefabricated housing has rapidly become the main alternative in the construction of affordable, environmentally friendly, and modern homes [10].

The problem is, prefabricated house systems are very dependent on the community readiness, innovative approaches, appropriate materials selection, methods, and techniques in development [11]. Some countries in Asia still do not use this system because of different social and economic characteristics. Asian countries tend to use conventional systems with more field workforce than prefabricated systems. This is partly due to the fact that labor costs for construction work in Asia are far lower than those in developed countries such as the United States [12].

In Indonesia itself, the use of prefabricated systems in residential construction is not yet widely known by the community and its use is still limited to a number of temporary needs such as worker mess, temporary offices, or shelter for victims of natural disasters [5]. Prefabricated housing is not very popular in Indonesia because it has cheap stigma, low quality, limited design preferences, and is temporary [10]. Some companies that have developed prefabricated house systems in Indonesia can be seen in table 2:

TABLE II. PrefabricATEd House SySTEM PRoviders

\begin{tabular}{|c|c|c|c|c|}
\hline $\begin{array}{c}\text { Prefab } \\
\text { level }\end{array}$ & Function & Area & Features & $\begin{array}{l}\text { Prefab } \\
\text { System } \\
\end{array}$ \\
\hline $\begin{array}{l}\text { Rumah } \\
\text { Instan } \\
\text { Sederhana } \\
\text { Sehat } \\
\text { (RISHA) }\end{array}$ & $\begin{array}{l}\text { Temporary mass } \\
\text { housing, disaster } \\
\text { post } \\
\text { housing, low cost } \\
\text { permanent single } \\
\text { family housing }\end{array}$ & $\begin{array}{l}21-45 m^{2}, \\
1-2 \text { floor }\end{array}$ & $\begin{array}{l}2 \text { Bedrooms } \\
1 \text { Bathroom } \\
\text { Living room }\end{array}$ & $\begin{array}{l}\text { Panel } \\
\text { (precast } \\
\text { concrete) }\end{array}$ \\
\hline $\begin{array}{l}\text { Sanwa } \\
\text { Prefab }\end{array}$ & $\begin{array}{l}\text { Permanent single } \\
\text { family housing }\end{array}$ & $\begin{array}{l}60-96 \mathrm{~m}^{2} \\
1 \text { floor }\end{array}$ & $\begin{array}{l}2 \text { Bedrooms } \\
1 \text { Bathroom } \\
\text { Living room }\end{array}$ & $\begin{array}{l}\text { Panel } \\
\text { (metal } \\
\text { panel) }\end{array}$ \\
\hline JSteel & $\begin{array}{l}\text { Low cost single } \\
\text { family housing, } \\
\text { Post disaster housing }\end{array}$ & $\begin{array}{l}36-65 \mathrm{~m}^{2} \\
1 \text { floor }\end{array}$ & $\begin{array}{l}2 \text { Bedrooms } \\
1 \text { Bathroom } \\
\text { Living room }\end{array}$ & $\begin{array}{l}\text { Panel } \\
\text { (steel } \\
\text { frame, } \\
\text { Kalsi } \\
\text { board, } \\
\text { composit } \\
\text { e panel) }\end{array}$ \\
\hline BPanel & $\begin{array}{lr}\text { Low cost } & \text { single } \\
\text { family } & \text { housing, } \\
\text { temporary } & \text { mess } \\
\text { building, } & \text { post } \\
\text { disaster } & \text { housing, } \\
\text { warehouse } & \\
\end{array}$ & $\begin{array}{l}36-56 \mathrm{~m}^{2} \\
1 \text { floor }\end{array}$ & $\begin{array}{l}2 \text { Bedrooms } \\
1 \text { Bathroom } \\
\text { Living room }\end{array}$ & $\begin{array}{l}\text { Panel } \\
\text { (precast } \\
\text { concrete) }\end{array}$ \\
\hline $\begin{array}{l}\text { Tata } \\
\text { Logam }\end{array}$ & $\begin{array}{lr}\text { Permanent } & \text { single } \\
\text { family } & \text { housing, } \\
\text { temporary } & \text { mess } \\
\text { building, r post } & \text { pisaster housing } \\
\end{array}$ & $\begin{array}{l}21-45 m^{2} \\
1 \text { floor }\end{array}$ & $\begin{array}{l}2 \text { Bedrooms } \\
1 \text { Bathroom } \\
\text { Living room }\end{array}$ & $\begin{array}{l}\text { Compone } \\
\text { nt } \\
\text { (precut } \\
\text { steel } \\
\text { frame) }\end{array}$ \\
\hline $\begin{array}{l}\text { Bali } \\
\text { Prefab }\end{array}$ & Luxury villa & $\begin{array}{l}36-150 \mathrm{~m}^{2} \\
1-2 \text { floor }\end{array}$ & $\begin{array}{l}2 \text { Bedrooms } \\
1 \text { Bathroom } \\
\text { Living room } \\
\text { Kitchen } \\
\text { Dining area }\end{array}$ & $\begin{array}{l}\text { Wood } \\
\text { compone } \\
\text { nt } \\
\text { (precut) }\end{array}$ \\
\hline
\end{tabular}

From the portfolio of prefabricated house providers in Indonesia, can be concluded that most of prefabricated systems are still used for low-cost or post-disaster housing with an area less than $100 \mathrm{~m}^{2}$. Usually has 1 floor and most of them use panel systems with precast concrete structures or steel frames. Apart from these two prefabricated components, other components are still being worked on in the conventional field. This can eliminate the accuracy of the material, so that houses made from prefabricated components look dull and fragile. This is what ultimately gives the stigma that prefabricated houses are low-cost and low-quality houses [10].

Unlike the prefabricated systems in developed countries, almost all luxury prefabricated houses use a modular construction system. Field work only concerns the foundation, concrete floors, and foundation for the MEP (Mechanical, Electrical, and Plumbing) system. While the main structure, fill structure, wall panels, ceilings, roofs, and finishing are assembled as modules in the factory [10].

PT. Woodlam Indonesia Abadi (hereinafter referred to as Woodlam Indonesia) is a company established for around two years and has a product in the form of prefabricated houses with middle to upper market segmentation. The level of prefabrication provided by Woodlam Indonesia varies considerably from components, panels, modular, to complete buildings. The complete product portfolio is an advantage that can be utilized by companies to continue to develop prefabricated house systems in Indonesia.

In addition to the product portfolio, Woodlam Indonesia also proves itself as an innovative company in terms of the types of materials used. In making prefabricated houses, Woodlam Indonesia uses engineered wood in the form of Cross Laminated Timber, Glulam, and Structural Insulated Panel. These three types of material are the new types of engineered wood that are not yet widely known in Indonesia. The reason Woodlam Indonesia uses engineered wood because wood is a lightweight material and is suitable for application in prefabricated houses.

In terms of marketing channels, Woodlam Indonesia cooperates with architects who love to design a building with prefabricated systems for their clients. This channel selection has its own advantages and disadvantages. By collaborating with architects, especially those with good names, Woodlam Indonesia can build a company's brand image quickly. But on the other hand, this also causes dependency, the company seems to wait for the project from the architects, and it makes the company's cash flow become unstable.

In 2019, Woodlam Indonesia has a revenue target of 15 billion rupiahs. This target continues to grow to 25 billion in 2020, and 40 billion in 2021. These targets is not without reason. According to a report released by BCI Asia [13] in Construction magazine, in 2019 the market share of Indonesia's construction projects (building and civil projects, excluding oil and gas) is expected to decrease by 3.16 percent compared to 2018. This decline influenced by a slowdown in utility projects due to reduced government targets for electricity generation. However, the total Indonesian construction market is estimated to still have a value of around $\mathrm{Rp} 419.149$ trillion, of which 64 percent are in the civilian sector and 36 percent in the construction sector. The housing, industry building, and office categories are expected to be the biggest contributors to the 
total value of the building sector with 39 percent, 18 percent, and 10 percent respectively.

Figure 1 shows that in the future, the construction industry in Indonesia still has a promising prospects. Because the prefabrication system offered by Woodlam Indonesia is not limited to housing, but can target office buildings, retails, and hotels, so if we look at Woodlam Indonesia's target revenue in 2019 , they must capture at least $0.009 \%$ market share of the construction industry, especially in the building sector only.

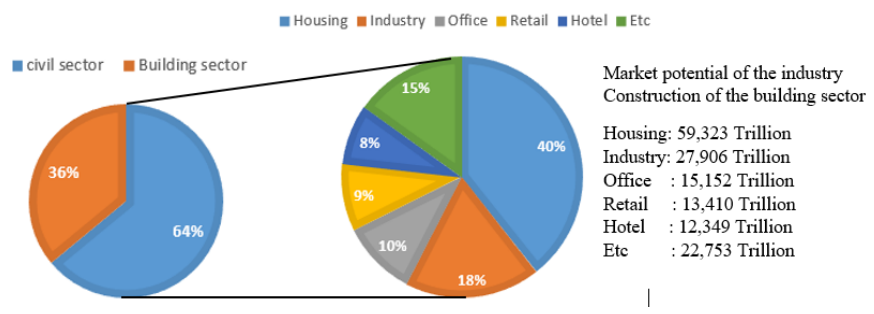

Fig. 1. Construction industry's market potential.

Unfortunately, the prefabricated system with a modular level offered by Woodlam Indonesia must be constrained by the transportation of material to the location. Modular systems require large containers and heavy machinery to unite the module system in the field. Besides, location accessibility is also an obstacle, the location must be in an area that has good road infrastructure for large vehicle traffic. The more remote a location is, the more modular the application of the system will be. This will be a major problem if the project obtained by Woodlam Indonesia is a hotel or resort in a remote location.

In addition to the community's readiness factor that needs to be continuously educated, Woodlam Indonesia must also know the specific Key Success Factor for the prefabricated home industry and maximize its strength in order to compete with its competitors. Based on the market study conducted by Berger in Central and Northern Europe, it was found that the Key Success Factors that influence the prefabricated house industry include [14]: the quality of the prefabricated house itself, the quality of the sales channel, product prices, product customization, and brands perception. In Indonesia, which has a different society and environment, of course this factor will be different. A separate analysis is needed on the key factors for the success of the prefabricated home industry that matches the competitive climate in Indonesia.

New companies with little experience, entering industries that are not yet widely known by the public, have high targets with ineffective marketing channels, and face fluctuating market share without having a systematic strategy formulation, then becomes the basis of this research with the aim of producing Woodlam Indonesia's business strategy for 20192021. Hopefully, the resulting strategy will not only make the company superior to its competitors, but also provide strategic steps to achieve the company's goals.

\section{LITERATURE REVIEW}

\section{A. External Analysis}

An external analysis has a purpose to find out a list of opportunities that can be exploited as well as threats that must be avoided by companies. Although external analysis is limited and does not specify all the factors that can affect the business, but this analysis can help companies in identifying key variables that offer responses to be followed up. The company is expected to be able to respond offensively and defensively to influential variables by formulating strategies that can take advantage of opportunities and minimize the impact of threats [15].

Things that must be considered when identifying and prioritizing external factors are making sure they are specific (quantifiable), actionable (meaningful in terms of having strategic implications), and expressed as external trends, events, or facts rather than as a strategy that can be done by the company. In conducting external analysis, two analytical tools are carried out, consist of Pestel and Porter's five forces model.

PESTEL is an acronym of the tool used to identify external factors faced by companies in a macro level. The acronym consists of Political, Economic, Social, Technological, Environmental, and Legal/law. Before the strategy is formulated, it is very important to conduct a PESTEL analysis. Companies that successfully monitor and respond to changes in the macro environment can create competitive advantage by capturing available opportunities and avoiding threats as early as possible [15]

In addition to macro factors, the situation in the industry also has a strong influence in determining competition rules and strategies available to companies. According to Porter, competition in an industry is rooted in the underlying economic structure and determines the behavior of current competitors [16]. There are five pressures that determine competition and affect the profit potential of an industry, consist of threat of new entrants, rivalry among existing competitors, threat of substitute products, bargaining power of buyers, and bargaining power of suppliers.

\section{B. External Factor Evaluation (EFE) Matrix}

External Factor Evaluation Matrix (EFE) is a tool that can help strategists summarize and evaluate macro factors (Political, Economic, Social, Technology, Environment, Legal / law) and industry (New entrants, Rivalry, Substitute products, Buyers, Suppliers). Regardless of the opportunity and threat factor included in the EFE matrix, the highest possible value is 4 and the lowest value is 1 . The weighted average is 2.5 . Value 4 indicates that the organization performs a very good response in overcoming all opportunities and threats in the industry. In other words, the company's strategy has effectively benefited from the opportunities and has minimized the potential of adverse impacts from the external [15]

\section{Competitor Analysis}

After analyzing Porter's 5 Forces Model, companies can use the results to determine the Key Success Factor (KSF) of the industry. When the industry has a good impact on the company, then the factors identified through Porter's analysis are favorable factors. Conversely, if Porter's analysis has an unfavorable effect, it will encourage the emergence of KSF to overcome these factors. Grant says that KSF arises from what customers want and how we survive competition [17].

The Competitive Profile Matrix (CPM) can identify who are the main competitors in an industry and compare the strengths and weaknesses of these competitors relative to the company's strategic position. The critical success factors in CPM include internal and external problems, therefore it has its 
own weighting system where values 4 (main strengths), 3 (small strengths), 2 (small weaknesses), and 1 (major weaknesses). This comparative analysis provides strategic information related to the company's position compared to competitors. The higher CPM value indicates a better company performance [15].

\section{Internal Analysis}

Internal analysis aims to see the strengths and weaknesses of each division in the company. Functions that are usually analyzed in this internal section include management, marketing, accounting, production/operations, research and development, and management of information systems. Internal analysis uses two analytical tools, consist of functional analysis and value chain analysis [15].

According to Porter, a company's business can be described as a value chain, where total revenue is reduced by the total cost of all activities undertaken to develop and market the products or services produced [16]. Almost all companies in an industry have a similar value chain, which usually includes various activities such as obtaining raw materials, designing products, building manufacturing facilities, developing cooperation agreements, and providing customer services. A company will benefit if the total revenue exceeds the total costs arising from the creation and delivery of products or services.

Value Chain analysis refers to the process by which companies determine costs associated with organizational activities ranging from purchasing raw materials, production, to marketing the product. The purpose of this Value Chain Analysis is to identify where the advantages of low costs and high costs that exist throughout the value chain from raw materials to customer service activities [15].

\section{E. Internal Factor Evaluation (IFE) Matrix}

Similar to EFE, the Internal Factor Evaluation Matrix (IFE) is a tool that can help strategists summarize and evaluate the main strengths and weaknesses in the functional side of a company. IFE analysis results can also be used as a basis for identifying and evaluating functional areas. Regardless of the strength or weakness factor entered into the IFE matrix, the total value that will come out ranges from 1 to 4 with an average of 2.5. The total value below 2.5 indicates the company's internal weakness, while the total value is above 2.5 , indicating the company's strong internal position [15].

\section{F. Identify Alternative Strategies and Determine Priorities}

The analysis and selection of strategies will determine what alternative actions can help the company to achieve its mission and objectives. The company's strategies, goals, vision, and mission are now coupled with external and internal information, providing a basis for generating and evaluating viable alternative strategies. Not all alternative strategies will be used by the company. It might be because these alternative strategies require a lot of action or costs that might actually burden the company. For this reason, alternative strategies to be developed must be examined, prioritized, and then chosen. In addition, all the advantages, disadvantages, trade-offs, costs and benefits of the strategy must be determined as well.

Internal External (IE) Matrix is one of the means to determine strategy by matching internal resources and capabilities owned by the company as well as opportunities and threats faced by external factors. The IE matrix consists of two large dimensions, i.e. the total weighted average IFE on the $\mathrm{X}$ axis and the total weighted average EFE on the $\mathrm{Y}$ axis. On the $\mathrm{X}$ axis IE matrix, if the weighted average IFE is in the range of 1.0 to 1.99 , then this shows the weak internal position of the company; a score of 2.0 to 2.99 is considered average; and a score of 3.0 to 4.0 is considered to have a strong internal position. Likewise on the $\mathrm{Y}$ axis, the weighted average EFE from 1.0 to 1.99 will be considered low; a score of 2.0 to 2.99 will be considered moderate; and a score of 3.0 to 4.0 will be considered high [15].

According to Weihrich, TOWS matrix is a tool to classify opportunities and threats from the external environment with strengths and weaknesses in the internal environment [18]. This grouping will produce 4 types of strategies, namely SO (strengths-opportunities) strategy, WO (weaknessesopportunities) strategy, ST (strengths-threats) strategy, and WT (weaknesses-threats) strategy.

After getting alternative strategies, the next step that needs to be done is to evaluate the selected strategy and determine the priority of the strategy. This can be done using a tool called the Quantitative Strategic Planning Matrix (QSPM). QSPM uses input from EFE and IFE, matches it with the results of the TOWS analysis, then chooses which strategy is the most likely of all alternatives.

\section{RESEARCH METHOD}

The type of data used is qualitative data where the data obtained in the form of information, description, and translation. If the data obtained is quantitative data, it will be discussed and used qualitatively as an analytical material to provide an alternative company strategy for the next three years. As for the qualitative data included in this study is a general description of the company, including: A brief history of Woodlam Indonesia, geographical location, vision and mission, organizational structure, employee situation, and company infrastructure.

The data source is the place or origin of the desired data, this is important to know so that there are no mistakes in choosing a source that is suitable for the purpose of the study. In this study the authors used two data sources, namely primary data sources and secondary data sources. The method or technique of collecting data is the way the researcher does to obtain the required data. In this study data collection was carried out using several methods, namely observation, interviews, and literature study.

The observation method used in this study is direct and unstructured observation. Direct observation means the researcher is fully involved in observation, observing directly what is done, listening to what is said, and participating in company activities. While unstructured means that observations are not made using rigid charts or guidelines, so researchers can develop their observations based on developments that occur in the field.

While interviews are used by researchers to find out the strategies that have been implemented by Woodlam Indonesia in previous years, starting from the time they were established until now. The interview conducted by the researcher is a type of unstructured in-depth interview where the researcher prepares a list of questions, but when conducting interviews, 
questions can develop with new questions that come to mind. Data sources or respondents in this interview are Jeshua Sadeli as the company director and the people who pioneered the founding of Woodlam Indonesia.

Literature study is conducted to obtain secondary data related to strategic management theories that are relevant to company conditions. In addition, a document study was also conducted to determine the state of the external environment and the state of the industry that affected Woodlam Indonesia. These data was obtained from scientific books, research journals, magazines, news articles, websites, survey reports by consultants, statistical data, and government policies.

All data obtained through literature studies, observations, and interviews will be filtered based on relevance. The relevant data is then used for external and internal analysis. External analysis uses two analytical tools in the form of PESTEL and 5 Porter's competitive forces. While internal analysis uses functional analysis and value chain analysis. In addition, a CPM (Competitive Profile Matrix) analysis based on the KSF (Key Success Factor) was also conducted to determine the comparison of Woodlam Indonesia with its competitors, such as RISHA from WIKA Beton, BBI Prefab from PT. Bakrie, prefab house from PT. Jaindo Metal Industries, and Bhome from PT. Beton Elemenindo Putra.

Relevant issues obtained from the PESTEL analysis, Porter's 5 competitive forces, and CPM are then grouped in the opportunity and threat category in the EFE matrix. These opportunities and threats are then weighted based on their importance to the construction industry and are judged based on how companies respond to these issues. Each weight is multiplied by the rating, then summed to produce the total value of the EFE matrix.

From functional analysis, value chain, and CPM obtained strengths and weaknesses of the company which will be summarized in the IFE matrix. Like the work of external analysis, weighting and valuation are given to each company's strengths and weaknesses. Next, weights and values are calculated and added to produce the total value of the IFE matrix.

Values from the EFE and IFE matrix analysis are then included in the $\mathrm{I} / \mathrm{E}$ matrix to find out the type of relevant strategy. The type of strategy is then adjusted to the alternative strategies created by the TOWS matrix. This matrix is obtained through comparison of the company's internal strengths and weaknesses with opportunities and threats from the external environment. Of the many alternative strategies, QSPM tools are used to select and prioritize the most interesting strategies.

\section{ANALYSIS AND DISCUSSION}

\section{A. External Analysis}

The growth and development of the company is greatly influenced by external factors, both macro and industry. These external factors determine the potential opportunities and potential threats that the company may face in the future. In this discussion, external factors are seen by using two analytical tools, PESTEL and Porter's five Forces.

Based on data obtained from macro factors, especially politics, economics, social, technology, environment, and law / legal, the PESTEL analysis of the prefabricated house construction industry can be summarized in Table 3 .

TABLE III. PREFABRICATED SYSTEM CATEGORIES

\begin{tabular}{|c|c|c|c|}
\hline Factor & Situation & Impact & Classification \\
\hline \multirow{3}{*}{ Politics } & $\begin{array}{l}\text { The one million } \\
\text { house program } \\
\text { initiated by the } \\
\text { government }\end{array}$ & $\begin{array}{l}\text { Increasing housing } \\
\text { needs with a fast } \\
\text { development } \\
\text { system }\end{array}$ & Opportunities \\
\hline & $\begin{array}{l}\text { Cooperation contract } \\
\text { with the Philippines } \\
\text { (Revolution pre- } \\
\text { crafted) }\end{array}$ & $\begin{array}{l}\text { The emergence of } \\
\text { new competitors in } \\
\text { the prefabricated } \\
\text { house construction } \\
\text { industry }\end{array}$ & Threats \\
\hline & $\begin{array}{l}\text { Kemenpar's policy to } \\
\text { develop } 10 \text { new Bali } \\
\text { destinations }\end{array}$ & $\begin{array}{l}\text { Increasing demand } \\
\text { for } \\
\text { accommodations } \\
\text { such as villas and } \\
\text { resorts }\end{array}$ & Opportunities \\
\hline \multirow{4}{*}{$\begin{array}{l}\text { Economic } \\
\mathrm{s}\end{array}$} & $\begin{array}{l}\text { The construction } \\
\text { sector ranks first in } \\
\text { the PMDN and the } \\
\text { housing sector ranks } \\
\text { third in the PMA }\end{array}$ & $\begin{array}{l}\text { Large additional } \\
\text { capital can make } \\
\text { the construction / } \\
\text { housing sector } \\
\text { grow }\end{array}$ & Opportunities \\
\hline & $\begin{array}{l}\text { House prices continue } \\
\text { to rise every year }\end{array}$ & $\begin{array}{lr}\text { Consumer } & \text { demand } \\
\text { in building new } \\
\text { homes } & \text { will } \\
\text { decrease } & \\
\end{array}$ & Threats \\
\hline & $\begin{array}{l}\text { The emergence of } \\
\text { mortgage programs } \\
\text { for millennial }\end{array}$ & \multirow{2}{*}{$\begin{array}{l}\text { People are } \\
\text { increasingly easy to } \\
\text { buy a house }\end{array}$} & \multirow{2}{*}{ Opportunities } \\
\hline & $\begin{array}{l}\text { New housing finance } \\
\text { subsidies } \\
\text { schemes }\end{array}$ & & \\
\hline \multirow{4}{*}{ Social } & $\begin{array}{l}\text { Increase in population } \\
\text { and productive age }\end{array}$ & $\begin{array}{l}\text { The number of } \\
\text { housing needs } \\
\text { increases }\end{array}$ & Opportunities \\
\hline & $\begin{array}{l}\begin{array}{l}\text { Shifting } 50 \text { million } \\
\text { lower } \\
\text { population }\end{array} \\
\begin{array}{l}\text { pop middle } \\
\text { class }\end{array}\end{array}$ & $\begin{array}{l}\text { The purchasing } \\
\text { power of the } \\
\text { community towards } \\
\text { the home increases }\end{array}$ & Opportunities \\
\hline & $\begin{array}{l}\text { The millennial } \\
\text { segment prefers } \\
\text { houses with open } \\
\text { spaces and is very } \\
\text { concerned about } \\
\text { building aesthetics }\end{array}$ & \multirow{2}{*}{$\begin{array}{l}\text { Interest in using } \\
\text { prefabricated } \\
\text { houses decreases } \\
\text { because the shape } \\
\text { tends to be } \\
\text { monotonous and } \\
\text { seems cheap }\end{array}$} & \multirow[t]{2}{*}{ Threats } \\
\hline & $\begin{array}{l}\text { Negative public } \\
\text { perception of } \\
\text { prefabricated houses }\end{array}$ & & \\
\hline $\begin{array}{l}\text { Technolog } \\
\mathrm{y}\end{array}$ & $\begin{array}{l}\text { Adoption of } \\
\text { technology is slow in } \\
\text { the construction } \\
\text { sector }\end{array}$ & $\begin{array}{l}\text { The development } \\
\text { of the prefabricated } \\
\text { house industry is } \\
\text { slow }\end{array}$ & Threats \\
\hline \multirow{2}{*}{$\begin{array}{l}\text { Environm } \\
\text { ent }\end{array}$} & $\begin{array}{l}\text { Indonesia's } \\
\text { commitment in } \\
\text { Nationally } \\
\text { Determined } \\
\text { Contribution (NDC) } \\
\text { to issue a low carbon } \\
\text { policy }\end{array}$ & $\begin{array}{lr}\text { Demand } & \text { for } \\
\text { prefabricated } & \\
\text { houses } & \text { with } \\
\text { environmentally } \\
\text { friendly } & \text { raw } \\
\text { materials } & \text { will } \\
\text { increase } & \\
\end{array}$ & Opportunities \\
\hline & $\begin{array}{l}\text { Scarcity of quality } \\
\text { raw materials }\end{array}$ & $\begin{array}{l}\text { The quality of } \\
\text { products produced } \\
\text { by companies in } \\
\text { the prefabricated } \\
\text { home industry may } \\
\text { decline }\end{array}$ & Threats \\
\hline $\begin{array}{l}\text { Law/Lega } \\
1\end{array}$ & $\begin{array}{l}\text { The absence of } \\
\text { regulations governing } \\
\text { the construction of } \\
\text { houses using the } \\
\text { prefabrication method }\end{array}$ & $\begin{array}{l}\text { The development } \\
\text { of the prefabricated } \\
\text { house industry is } \\
\text { slow }\end{array}$ & Threats \\
\hline
\end{tabular}

Source: Analyzed by writer (2019)

Porter's Five Forces is used to determine the level of industry's profitability. In this case, the chosen industry is in the construction sector, more specifically the construction of 
houses using a prefabricated system. Companies that are included in this industry category are companies that provide materials and services in the construction of houses whose components have been previously produced at the factory, and then installed in the field.

To find out the capability of the prefabricated house construction industry, Porter's five forces analysis tools consisted of Rivalry Among Existing Firms, Threat of New Entrants, Threat of Substitute Products, Bargaining Power of Buyers, and Bargaining Power of Suppliers (table 4).

TABLE IV. PREFABRICATED SYSTEM CATEGORIES

\begin{tabular}{|c|c|c|c|}
\hline Aspect & Factor & $\begin{array}{c}\text { Favorable/U } \\
\text { nfavorable }\end{array}$ & Impact \\
\hline \multirow{5}{*}{$\begin{array}{l}\text { Rivalry } \\
\text { Among } \\
\text { Existing } \\
\text { Firms }\end{array}$} & Diversity of competitors & Favorable & \multirow{5}{*}{$\begin{array}{l}\text { Rivalry } \\
\text { competitors in the } \\
\text { industry } \\
\text { relatively low, so } \\
\text { this condition is } \\
\text { favorable for } \\
\text { companies } \\
\text { engaged } \\
\text { construction }\end{array}$} \\
\hline & Switching cost & Favorable & \\
\hline & Brand identity & Favorable & \\
\hline & Product differentiation & Favorable & \\
\hline & $\begin{array}{l}\text { Concentration of players } \\
\text { in the industry }\end{array}$ & Favorable & \\
\hline \multirow{6}{*}{$\begin{array}{l}\text { Threat of } \\
\text { New } \\
\text { Entrants }\end{array}$} & Economies of scale & Favorable & \multirow{6}{*}{$\begin{array}{l}\text { Barriers to } \\
\text { entering the } \\
\text { industry are } \\
\text { relatively high, so } \\
\begin{array}{l}\text { this condition is } \\
\text { favorable for } \\
\text { companies } \\
\begin{array}{l}\text { engaged } \\
\text { construction }\end{array}\end{array}\end{array}$} \\
\hline & Capital & Favorable & \\
\hline & Knowledge/experience & Favorable & \\
\hline & Mastery of technology & Favorable & \\
\hline & Brand identity & Unfavorable & \\
\hline & Government policy & Unfavorable & \\
\hline \multirow{4}{*}{$\begin{array}{l}\text { Threat of } \\
\text { Substitute } \\
\text { Products }\end{array}$} & $\begin{array}{l}\text { Price of substitute } \\
\text { products }\end{array}$ & Unfavorable & \multirow{4}{*}{$\begin{array}{l}\text { The threat of } \\
\text { substitute products } \\
\text { in the industry is } \\
\text { relatively high, so } \\
\text { this condition is } \\
\text { detrimental to } \\
\text { companies } \\
\text { engaged } \\
\text { construction }\end{array}$} \\
\hline & $\begin{array}{l}\text { Quantity of substitute } \\
\text { products }\end{array}$ & Unfavorable & \\
\hline & Switching cost & Unfavorable & \\
\hline & $\begin{array}{l}\text { Buyer's intention to use } \\
\text { substitute products }\end{array}$ & Unfavorable & \\
\hline \multirow{7}{*}{$\begin{array}{l}\text { Bargainin } \\
g \text { Power } \\
\text { of Buyers }\end{array}$} & $\begin{array}{l}\text { Concentration of the } \\
\text { buyer }\end{array}$ & Favorable & \multirow{7}{*}{$\begin{array}{l}\text { The bargaining } \\
\text { power } \\
\text { customers in the } \\
\text { industry } \\
\text { relatively high, so } \\
\text { this condition is } \\
\text { detrimental to } \\
\text { companies } \\
\text { engaged } \\
\text { construction }\end{array}$} \\
\hline & Information for buyers & Favorable & \\
\hline & Product differentiation & Favorable & \\
\hline & Product quality & Unfavorable & \\
\hline & Brand identity & Unfavorable & \\
\hline & The number of buyers & Unfavorable & \\
\hline & Product substitution & Unfavorable & \\
\hline \multirow[b]{4}{*}{$\begin{array}{l}\text { Bargainin } \\
\mathrm{g} \text { Power } \\
\text { of } \\
\text { Suppliers }\end{array}$} & Input differentiation & Favorable & \multirow{4}{*}{$\begin{array}{l}\text { The bargaining } \\
\text { power of suppliers } \\
\text { in the industry is } \\
\text { relatively low, so } \\
\text { this condition is } \\
\text { advantageous for } \\
\text { companies } \\
\text { engaged } \\
\text { construction in }\end{array}$} \\
\hline & Substitution suppliers & Favorable & \\
\hline & Supplier concentration & Favorable & \\
\hline & Quality of raw materials & Unfavorable & \\
\hline
\end{tabular}

After analyzing PESTEL and Porter's five forces, the results are then compiled into an External Factor Evaluation (EFE) matrix to facilitate researchers in evaluating the potential opportunities and threats faced by the company. This matrix shows the readiness and capability of the company to take advantage of opportunities and anticipate threats that are or may occur in the future. In this matrix every opportunity and threat is grouped into one category and is given a weight based on its influence on the company's revenue and costs. After being given a weight, then each opportunity and threat will be assessed based on the company's response in capturing the opportunity and overcoming the threat. The following is a summary of the EFE tables 5:

TABLE V. EXTERNAL FACTOR EVALUATION (EFE) MATRIX

\begin{tabular}{|c|c|c|c|}
\hline Opportunities & Weight & Rating & $\begin{array}{l}\text { Weighted } \\
\text { Score }\end{array}$ \\
\hline $\begin{array}{l}\text { The one million house program } \\
\text { initiated by the government }\end{array}$ & 0,100 & 2 & 0,200 \\
\hline $\begin{array}{l}\text { Kemenpar's policy to develop } 10 \\
\text { new Bali destinations }\end{array}$ & 0,125 & 3 & 0,375 \\
\hline $\begin{array}{l}\text { The emergence of mortgage } \\
\text { programs for millennial, new } \\
\text { housing finance subsidies, and } \\
\text { schemes }\end{array}$ & 0,075 & 1 & 0,075 \\
\hline $\begin{array}{l}\text { Shifting } 50 \text { million lower class } \\
\text { population to middle class }\end{array}$ & 0,150 & 4 & 0,600 \\
\hline $\begin{array}{l}\text { Indonesia's commitment in } \\
\text { Nationally } \\
\text { Contribution (NDC) to issue a low } \\
\text { carbon policy }\end{array}$ & 0,050 & 2 & 0,100 \\
\hline Threats & Weight & Rating & $\begin{array}{l}\text { Weighted } \\
\text { Score }\end{array}$ \\
\hline $\begin{array}{l}\text { House prices continue to rise every } \\
\text { year }\end{array}$ & 0,100 & 2 & 0,200 \\
\hline $\begin{array}{l}\text { The millennial segment prefers } \\
\text { houses with open spaces and is very } \\
\text { concerned about building aesthetics }\end{array}$ & 0,075 & 3 & 0,225 \\
\hline $\begin{array}{l}\text { Negative public perception of } \\
\text { prefabricated houses }\end{array}$ & 0,150 & 2 & 0,300 \\
\hline $\begin{array}{l}\text { Adoption of technology is slow in } \\
\text { the construction sector }\end{array}$ & 0,125 & 4 & 0,500 \\
\hline \multirow[t]{2}{*}{$\begin{array}{l}\text { The absence of regulations } \\
\text { governing the construction of } \\
\text { houses using the prefabrication } \\
\text { method }\end{array}$} & 0,050 & 1 & 0,050 \\
\hline & 1 & 24 & 2,625 \\
\hline
\end{tabular}

The EFE score produced by Woodlam Indonesia is 2,625. This shows that the company has done a fairly good response in capturing all opportunities and overcoming threats that occur in the prefabricated house construction industry. The strategy that has been carried out by the company has been quite effective in taking advantage of opportunities and minimizing the adverse effects of external threats. This value also indicates that the company still has a chance to make improvements or changes in strategy to be even better in the future.

\section{B. Competitor Analysis}

As a company focused in the construction of prefabricated houses, Woodlam Indonesia's direct competitors are companies that sell similar products or methods, namely prefabricated houses. Regardless of the material used, whether it is precast concrete or steel which still requires a lot of work in the field, as long as it provides components, panels or modular systems produced at the factory, the company can be categorized as a direct competitor. At present there are already several companies that are trying to sell prefabricated houses, including Sanwa Prefab, Bpanel, Tatalogam, Arumdalu, and Bali Prefab.

Whereas indirect competitor for Woodlam Indonesia is a company focused in the conventional home construction industry. The company is included in the category of indirect competitors because ultimately what is needed by consumers is a house, regardless of the method used in the form of prefabricated or conventional. In addition, companies focused 
in the conventional home construction industry also took potential customers and market shares targeted by the company.

Industrial capability analysis is an analysis that shows how aspects of an industry can influence how difficult or easy a company in the industry can benefit through its business. When an aspect is favorable, it is considered to provide benefits to the company, whereas if the aspect is unfavorable, then it is considered to give a loss to the company. To overcome the unfavorable aspects of the industry, then Key Success Factor or key success factors emerge as a solution to win the competition.

In the prefabricated house construction industry, there are five key success factors that can be identified as answers to overcome the high threat of substitute products and bargaining power of customers. These five factors are good product quality, competitive prices, speed in development, ability in product customization, and effective promotion, as can be seen in table 6:

TABLE VI. KEy SUCCESS FACTOR (KSF) IDENTIFICATION

\begin{tabular}{|l|l|l|}
\hline \multicolumn{1}{|c|}{ Aspects } & \multicolumn{1}{|c|}{$\begin{array}{c}\text { Favorable/ } \\
\text { Unfavorable }\end{array}$} & \multicolumn{1}{|c|}{ KSF } \\
\hline $\begin{array}{l}\text { Rivalry Among Existing } \\
\text { Firms }\end{array}$ & F & - \\
\hline Threat of New Entrants & F & - \\
\hline
\end{tabular}

Table 6. Cont

\begin{tabular}{|l|l|l|}
\hline $\begin{array}{l}\text { Threat of Subtitute } \\
\text { Products }\end{array}$ & $\mathrm{U}$ & $\begin{array}{l}\text { 1. Good quality } \\
\text { 2. Competitive prices } \\
\text { 3. Speed in installation } \\
4 . \quad \begin{array}{c}\text { Ease of } \\
\text { customization }\end{array}\end{array}$ \\
\hline $\begin{array}{l}\text { Bargaining Power of } \\
\text { Buyers }\end{array}$ & $\mathrm{U}$ & $\begin{array}{l}\text { 1. Good quality } \\
\text { 2. Competitive prices } \\
\text { 3. Effective promotion }\end{array}$ \\
\hline $\begin{array}{l}\text { Bargaining Power of } \\
\text { Suppliers }\end{array}$ & $\mathrm{F}$ & - \\
\hline
\end{tabular}

The Competitive Profile Matrix (CPM) is one of the matrices used to show a comparison between the strengths and weaknesses of a company relative to its competitors based on Key Success Factor (KSF) in the industry in which the company competes. In this Competitive Profile Matrix, Woodlam Indonesia's competitive strength is analyzed based on the five Key Success Factors which include product quality, competitive prices, speed of development, product customization, and effective promotion.

The selected competitors in the CPM are competitors who are considered quite capable of describing the prefabricated home industry as a whole. Bali prefab was chosen because it offers prefabricated houses made of wood, Tatalogam made of mild steel, and Risha was chosen to represent prefabricated houses using precast concrete. These three competitor companies are also considered quite successful in introducing prefabricated houses even with different raw materials. The table below shows each company's Competitive Profile Matrix.

TABLE VII. COMPETITIVE PROFILE MATRIX (CPM) IDENTIFICATION

\begin{tabular}{|c|c|c|c|c|c|c|c|c|c|}
\hline \multirow[t]{2}{*}{ KSF } & \multirow{2}{*}{ WEIGHT } & \multicolumn{2}{|c|}{ Woodlam } & \multicolumn{2}{|c|}{ Bali Prefab } & \multicolumn{2}{|c|}{ TataLogam } & \multicolumn{2}{|c|}{ Risha } \\
\hline & & $S c$ & $W S$ & $S c$ & $W S$ & $S c$ & $W S$ & $S c$ & $W S$ \\
\hline Good quality & 0,25 & 4 & 1 & 3 & 0,75 & 2 & 0,5 & 1 & 0,25 \\
\hline $\begin{array}{l}\text { Competitive } \\
\text { prices }\end{array}$ & 0,23 & 1 & 0,23 & 2 & 0,46 & 3 & 0,69 & 4 & 0,92 \\
\hline $\begin{array}{l}\text { Speed in } \\
\text { installation }\end{array}$ & 0,23 & 2 & 0,46 & 2 & 0,46 & 4 & 0,92 & 3 & 0,69 \\
\hline $\begin{array}{l}\text { Ease of } \\
\text { customizatio } \\
\mathrm{n}\end{array}$ & 0,17 & 4 & 0,68 & 3 & 0,51 & 2 & 0,34 & 1 & 0,17 \\
\hline $\begin{array}{l}\text { Effective } \\
\text { promotion }\end{array}$ & 0,12 & 3 & 0,36 & 4 & 0,48 & 4 & 0,48 & 1 & 0,12 \\
\hline TOTAL & 1 & 14 & 2,73 & 14 & 2,66 & 14 & 2,93 & 10 & 2,15 \\
\hline
\end{tabular}

Based on table 7 the analysis of the Competitive Profile Matrix, the value of Woodlam Indonesia is 2.73. This shows that Woodlam Indonesia's performance is better and more competitive compared to Bali prefab and Risha, but lower when compared to Tatalogam.

\section{Internal Analysis}

There is no single company that is strong or weak in all areas, each company has specific strengths and weaknesses in each functional area. For this reason, Internal Analysis is needed to determine the strengths and weaknesses of Woodlam Indonesia to be ready to compete in the prefabricated house construction industry. In this internal analysis two analytical tools are used, namely functional analysis and value chain analysis.
Based on data obtained from functional analysis, specifically marketing, operations, human resources, and finance, the functional analysis of Woodlam Indonesia can be summarized in table 8:

TABLE VIII. FUNGSIONAL ANALYSIS WOODLAM INDONESIA

\begin{tabular}{|c|l|l|l|}
\hline Aspect & \multicolumn{1}{|c|}{ KSF } & Classification & \multicolumn{1}{|c|}{ Situation } \\
\hline \multirow{5}{*}{$\begin{array}{l}\text { Effective } \\
\text { Promotion }\end{array}$} & Strength & $\begin{array}{l}\text { Having a good marketing } \\
\text { channel }\end{array}$ \\
\cline { 3 - 4 } & Strength & $\begin{array}{l}\text { Strong branding in the eyes of } \\
\text { consumers }\end{array}$ \\
\cline { 3 - 4 } & Strength & $\begin{array}{l}\text { The products offered are } \\
\text { environmentally friendly and } \\
\text { sustainable }\end{array}$ \\
\cline { 3 - 4 } & Weaknesses & $\begin{array}{l}\text { Digital marketing has not } \\
\text { been managed well }\end{array}$ \\
\cline { 2 - 4 } & $\begin{array}{l}\text { Competitive } \\
\text { Price }\end{array}$ & Weaknesses & $\begin{array}{l}\text { The price offered by } \\
\text { Woodlam Indonesia is high }\end{array}$ \\
\hline
\end{tabular}


Table 8. Cont.

\begin{tabular}{|c|c|c|c|}
\hline Operation & $\begin{array}{l}\text { Good quality } \\
\text { product }\end{array}$ & Strength & $\begin{array}{l}\text { Support from the parent } \\
\text { company which has been } \\
\text { operating for } 40 \text { years }\end{array}$ \\
\hline & & Weaknesses & $\begin{array}{l}\text { Still taking corrective rather } \\
\text { than preventive action }\end{array}$ \\
\hline & $\begin{array}{l}\text { Speed in } \\
\text { installation }\end{array}$ & Weaknesses & $\begin{array}{l}\text { Lead time for quotation takes } \\
\text { time }\end{array}$ \\
\hline & $\begin{array}{l}\text { Ease of } \\
\text { customizatio } \\
\mathrm{n}\end{array}$ & Strength & $\begin{array}{l}\text { Has a production line that can } \\
\text { accommodate customization } \\
\text { systems }\end{array}$ \\
\hline \multirow[b]{2}{*}{$\begin{array}{l}\text { Human } \\
\text { Resource }\end{array}$} & \multirow[t]{2}{*}{$\begin{array}{l}\text { Speed in } \\
\text { installation }\end{array}$} & Weaknesses & $\begin{array}{l}\text { There is no human resource } \\
\text { division }\end{array}$ \\
\hline & & Weaknesses & $\begin{array}{l}\text { The absence of training } \\
\text { programs or employee } \\
\text { development resulting in a } \\
\text { limited workforce that is } \\
\text { competent }\end{array}$ \\
\hline Finance & $\begin{array}{l}\text { Competitive } \\
\text { prices }\end{array}$ & Weaknesses & $\begin{array}{l}\text { Limited company capital } \\
\text { because it still comes from } \\
\text { shareholder loans }\end{array}$ \\
\hline $\begin{array}{l}\text { Research } \\
\text { and } \\
\text { Developm } \\
\text { ent }\end{array}$ & $\begin{array}{l}\text { Ease of } \\
\text { customizatio } \\
\mathrm{n}\end{array}$ & Strength & $\begin{array}{l}\text { Having a culture to always } \\
\text { innovate and do research in } \\
\text { every division of the company }\end{array}$ \\
\hline
\end{tabular}

Source: Analyzed by writer (2019)

After conducting functional analysis and Value Chain, the results are then compiled into an Internal Factor Evaluation (IFE) matrix to facilitate researchers in summarizing and evaluating the strengths and weaknesses of the company. In this table, each strength and weakness is grouped and given a weight based on its influence on the company's revenue and costs. After being given a weight, then each strength and weakness will be assessed based on the company's response in maximizing strengths and overcoming these weaknesses. The following is a summary of the IFE table 9 :

TABLE IX. INTERNAL FACTOR EVALUATION (IFE) MATRIX

\begin{tabular}{|l|l|l|l|}
\hline \multicolumn{1}{|c|}{ Strengths } & Weight & Rating & \multicolumn{1}{|l|}{$\begin{array}{c}\text { Weighted } \\
\text { Score }\end{array}$} \\
\hline Having aood marketing channel & 0,10 & 3 & 0,30 \\
\hline $\begin{array}{l}\text { Support from the parent company } \\
\text { which has been operating for 40 years }\end{array}$ & 0,20 & 4 & 0,80 \\
\hline $\begin{array}{l}\text { Has a production line that can } \\
\text { accommodate customization systems }\end{array}$ & 0,14 & 3 & 0,42 \\
\hline $\begin{array}{l}\text { Having a culture to always innovate } \\
\text { and do research in every division of } \\
\text { the company }\end{array}$ & 0,12 & 3 & 0,36 \\
\hline \multicolumn{1}{|c|}{ Weaknesses } & Weight & Rating & $\begin{array}{l}\text { Weighted } \\
\text { Score }\end{array}$ \\
\hline $\begin{array}{l}\text { The price offered by Woodlam } \\
\text { Indonesia is high }\end{array}$ & 0,18 & 1 & 0,18 \\
\hline Lead time for quotation takes time & 0,16 & 1 & 0,16 \\
\hline $\begin{array}{l}\text { Digital marketing has not been } \\
\text { managed well }\end{array}$ & 0,10 & 2 & 0,20 \\
\hline & $\mathbf{1}$ & $\mathbf{1 6}$ & $\mathbf{2 , 4 2}$ \\
\hline
\end{tabular}

The IFE score produced by Woodlam Indonesia is 2.42 . Even though they are in the moderate category (2.00-2.99), this value indicates that the company's internal is still weak because it is below the industry average, which is 2.5 . The strategy that has been done so far has not been effective enough in maximizing strengths or minimizing weaknesses that are owned by the company. This value also indicates that the company must make an increase or change in strategy to be even better in the future.

\section{Internal Analysis}

Based on the EFE and IFE values from external and internal analysis, it can be seen that the position of Woodlam Indonesia in the IE matrix is in quadrant $\mathrm{V}$ with an EFE value of 2.625 and an IFE value of 2.42. This Quadrant V states that Woodlam Indonesia should adopt a hold and maintain approach in which the company should continue to improve internal conditions, so that when external conditions grow conducive, Woodlam Indonesia is able to grow and compete in the industry. In this quadrant, a suitable strategy is market penetration and product development with a fixed focus on the current market.

The TOWS matrix has a role in providing a number of alternative strategies that can be carried out by Woodlam Indonesia in the future by comparing external and internal situations. All alternative strategies contained in this matrix are closely related to the hold and maintain approach obtained from the IE matrix, Ansoff's market penetration and product development strategies, and the strategy of differentiation focus from Porter's competitive strategy.

In obtaining strategies, Woodlam Indonesia can utilize strengths or minimize internal weaknesses to seize opportunities or avoid external threats. After some analysis, several alternative strategies that can be applied by Woodlam Indonesia in the future are obtained, as shown in table 10:

TABLE X. TOWS MATRIX WOODLAM INDONESIA

\begin{tabular}{|c|c|c|c|}
\hline & & \multicolumn{2}{|c|}{ Internal Factor } \\
\hline \multirow{5}{*}{\multicolumn{2}{|c|}{ TOWS MATRIX }} & Strengths & Weaknesses \\
\hline & & $\begin{array}{l}\text { 1. Having a good } \\
\text { marketing channel }\end{array}$ & $\begin{array}{l}\text { 1. The price } \\
\text { offered by } \\
\text { Woodlam } \\
\text { Indonesia is high }\end{array}$ \\
\hline & & $\begin{array}{l}\text { 2. Support from the } \\
\text { parent company } \\
\text { which has been } \\
\text { operating for } 40 \text { years }\end{array}$ & $\begin{array}{l}\text { 2. Lead time for } \\
\text { quotation takes } \\
\text { time }\end{array}$ \\
\hline & & $\begin{array}{l}\text { 3. Has a production } \\
\text { line that can } \\
\text { accommodate } \\
\text { customization } \\
\text { systems }\end{array}$ & $\begin{array}{l}3 . \quad \text { Digital } \\
\text { marketing has not } \\
\text { been managed well }\end{array}$ \\
\hline & & $\begin{array}{l}\text { 4. Having a culture to } \\
\text { always innovate and } \\
\text { do research in every } \\
\text { division of the } \\
\text { company }\end{array}$ & \\
\hline \multirow{4}{*}{$\begin{array}{c}\text { External } \\
\text { Factor }\end{array}$} & Opportunities & $\begin{array}{c}\text { Strengths- } \\
\text { Opportunities }\end{array}$ & $\begin{array}{l}\text { Weaknesses- } \\
\text { Opportunities }\end{array}$ \\
\hline & $\begin{array}{l}\text { 1. The one } \\
\text { million house } \\
\text { program } \\
\text { initiated by the } \\
\text { government }\end{array}$ & \multirow{3}{*}{$\begin{array}{l}\text { Developing } \\
\text { complementary } \\
\text { products }(\mathrm{S} 2, \mathrm{~S} 3, \mathrm{~S} 4 \text {, } \\
\text { O4) } \\
\text { Positioning itself as a } \\
\text { company that cares } \\
\text { about the } \\
\text { environment (S1,O5) }\end{array}$} & \multirow{3}{*}{$\begin{array}{l}\text { Establishing } \\
\text { strategic } \\
\text { partnerships with } \\
\text { banks or financial } \\
\text { service providers } \\
\text { to create a } \\
\text { prefabricated } \\
\text { home loan system } \\
\text { (W1,O3) }\end{array}$} \\
\hline & $\begin{array}{lr}\text { 2. Kemenpar's } \\
\text { policy ro } \\
\text { develop } r \\
\text { new } 10 \\
\text { destinations }\end{array}$ & & \\
\hline & $\begin{array}{l}3 . \text { The } \\
\text { emergence of } \\
\text { mortgage } \\
\text { programs for } \\
\text { millennial, } \\
\text { new housing } \\
\text { finance } \\
\text { subsidies, and } \\
\text { schemes }\end{array}$ & & \\
\hline
\end{tabular}


Table 10. Cont.

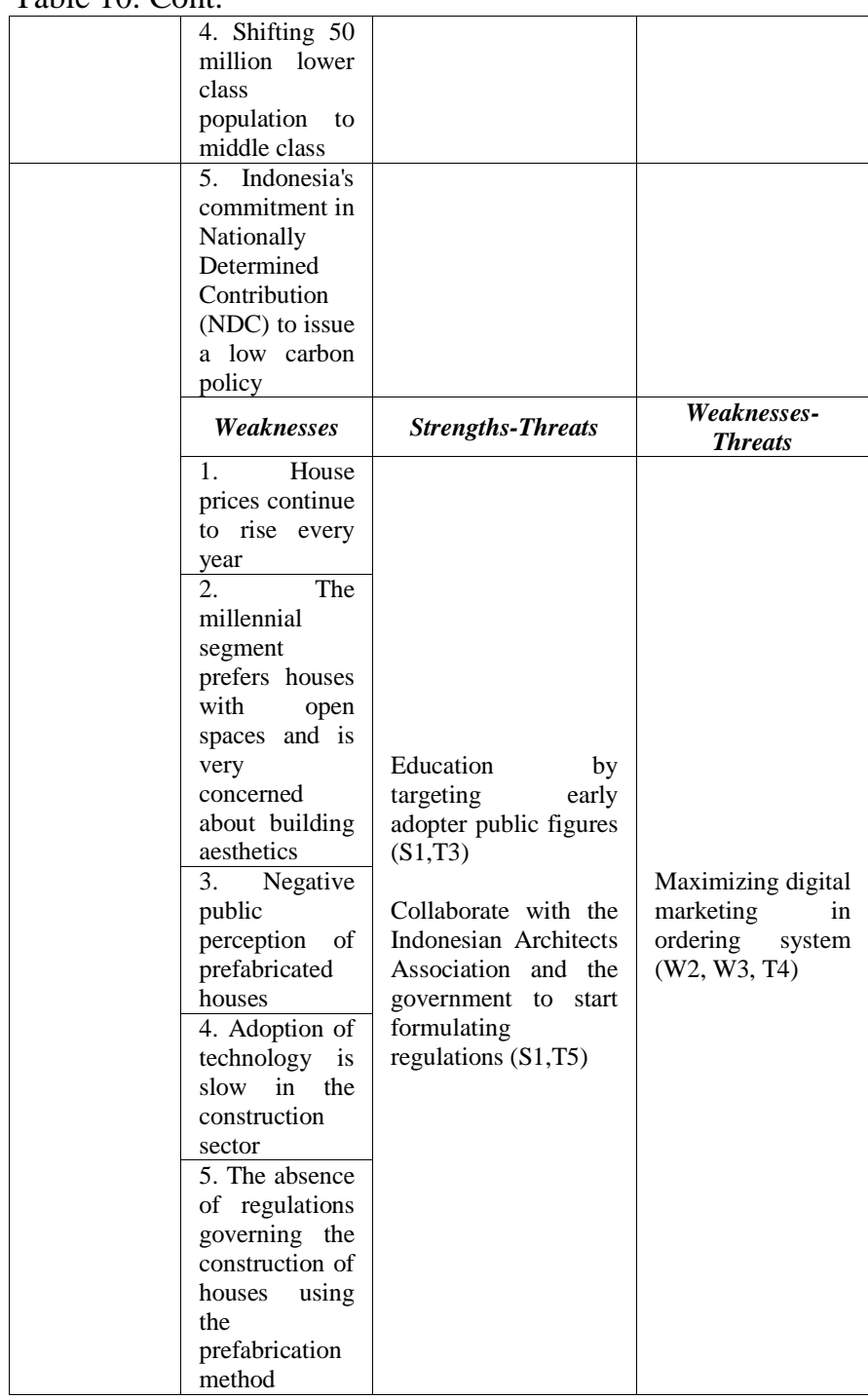

\section{E. Woodlam Indonesia's Chosen Strategies}

After formulating the strategy in the previous section, then in this stage a priority determination of several alternative strategies that have been recommended. The tool for determining priorities among several alternative strategies is called the QSPM (Quantitative Strategic Planning Matrix). By considering the results of the IFE, EFE and CPM, Woodlam Indonesia can group the strategies that have been produced by the SWOT matrix into two broad categories, namely:

The Quality of life strategy, which targets early adopter public figures to show the impression of luxury and quality in prefabricated houses (ST1), supported by competitive advantages related to environmentally friendly buildings (SO2) and promoted by maximizing digital marketing (WT1). This strategy targets massive awareness in the community, provides education, while creating a promotion system that maximizes digital marketing potential.

The second strategy is called Home for everybody. In this strategy besides selling prefabricated houses, Woodlam Indonesia also utilizes the support of the holding company to create complementary products (SO1). The target market is not as big as the first strategy, but it still carries product quality, which is supported through cooperation with banks or financial service providers to make the price of products affordable (WO1). So that the use of prefabricated houses is not constrained later, then Woodlam Indonesia also needs to work with the government to formulate regulations related to the method of constructing prefabricated houses (ST2)

The two strategies that have been produced are then entered into the QSPM matrix to see the priority of implementation, as can be seen in table 11:

TABLE XI. Quantitative StRategic PlanNing Matrix (QSPM)

\begin{tabular}{|c|c|c|c|c|c|}
\hline \multirow[t]{2}{*}{ KSF } & \multirow{2}{*}{$\begin{array}{c}\text { WEIG } \\
\text { HT }\end{array}$} & \multicolumn{2}{|c|}{$\begin{array}{c}\text { Quality of } \\
\text { Life }\end{array}$} & \multicolumn{2}{|c|}{$\begin{array}{c}\text { Home for } \\
\text { Everybody }\end{array}$} \\
\hline & & $A S$ & TAS & $A S$ & TAS \\
\hline \multicolumn{6}{|c|}{ Opportunities } \\
\hline $\begin{array}{l}\text { The one million house } \\
\text { program initiated by the } \\
\text { government }\end{array}$ & 0.100 & 1 & 0.100 & 3 & 0.30 \\
\hline $\begin{array}{l}\text { Kemenpar's policy to develop } \\
10 \text { new Bali destinations }\end{array}$ & 0.125 & 4 & 0.500 & 2 & 0.25 \\
\hline $\begin{array}{l}\text { The emergence of mortgage } \\
\text { programs for millennial, new } \\
\text { housing finance subsidies, } \\
\text { and schemes }\end{array}$ & 0.075 & 1 & 0.075 & 4 & 0.30 \\
\hline $\begin{array}{l}\text { Shifting } 50 \text { million lower } \\
\text { class population to middle } \\
\text { class }\end{array}$ & 0.150 & 3 & 0.450 & 2 & 0.30 \\
\hline $\begin{array}{l}\text { Indonesia's commitment in } \\
\text { Nationally } \text { Determined } \\
\text { Contribution (NDC) to issue } \\
\text { a low carbon policy }\end{array}$ & 0.050 & - & - & - & - \\
\hline \multicolumn{6}{|c|}{ Threats } \\
\hline $\begin{array}{l}\text { House prices continue to rise } \\
\text { every year }\end{array}$ & 0.100 & - & - & - & - \\
\hline $\begin{array}{l}\text { The millennial segment } \\
\text { prefers houses with open } \\
\text { spaces and is very concerned } \\
\text { about building aesthetics }\end{array}$ & 0.075 & - & - & - & - \\
\hline $\begin{array}{l}\text { Negative public perception of } \\
\text { prefabricated houses }\end{array}$ & 0.150 & 4 & 0.60 & 2 & 0.30 \\
\hline $\begin{array}{l}\text { Adoption of technology is } \\
\text { slow in the construction } \\
\text { sector }\end{array}$ & 0.125 & - & - & - & - \\
\hline $\begin{array}{l}\text { The absence of regulations } \\
\text { governing the construction of } \\
\text { houses using the } \\
\text { prefabrication method }\end{array}$ & 0.050 & 2 & 0.10 & 4 & 0.20 \\
\hline TOTAL & 1 & & & & \\
\hline \multicolumn{6}{|c|}{ Strengths } \\
\hline $\begin{array}{l}\begin{array}{l}\text { Having a good marketing } \\
\text { channel }\end{array} \\
\end{array}$ & 0.10 & 4 & 0.40 & 3 & 0.30 \\
\hline $\begin{array}{l}\text { Support from the parent } \\
\text { company which has been } \\
\text { operating for } 40 \text { years }\end{array}$ & 0.20 & 2 & 0.40 & 4 & 0.80 \\
\hline $\begin{array}{l}\text { Has a production line that } \\
\text { can accommodate } \\
\text { customization systems }\end{array}$ & 0.14 & 3 & 0.42 & 4 & 0.56 \\
\hline $\begin{array}{l}\text { Having a culture to always } \\
\text { innovate and do research in } \\
\text { every division of the } \\
\text { company }\end{array}$ & 0.12 & 4 & 0.48 & 2 & 0.24 \\
\hline \multicolumn{6}{|c|}{ Weaknesses } \\
\hline $\begin{array}{l}\text { The price offered by } \\
\text { Woodlam Indonesia is high }\end{array}$ & 0.18 & - & - & - & - \\
\hline $\begin{array}{l}\text { Lead time for quotation takes } \\
\text { time }\end{array}$ & 0.16 & - & - & - & - \\
\hline $\begin{array}{l}\text { Digital marketing has not } \\
\text { been managed well }\end{array}$ & 0.10 & 4 & 0.40 & 1 & 0.40 \\
\hline TOTAL & 1 & & 3.925 & & 3.65 \\
\hline
\end{tabular}


Based on the results of the score on the QSPM matrix, the Quality of life strategy scores 3,925 and the Home for Everybody strategy scores 3,65. Thus, the strategy that is more suitable prioritized by Woodlam Indonesia is the Quality of life strategy that focuses on market penetration.

\section{CONCLUSIONS, LIMITATIONS, AND SugGESTIONS}

Based on the analysis of external factors that have been identified in every aspect of the macro analysis, it can be concluded that the prefabricated home industry in Indonesia still has a good enough opportunity to continue to grow and develop with Indonesia's current macro conditions. This can be seen from the many opportunities that arise mainly from political, economic, and environmental aspects in the midst of several threats such as technological and legal aspects. Based on the results of industry analysis, the prefabricated house construction industry in Indonesia also has good prospects, although there are several aspects that still have the potential to hamper industrial development such as the high threat of substitute goods and consumer bargaining power. Therefore, companies engaged in the prefabricated house industry need to pay attention to several key success factors that are very useful in overcoming aspects that hinder the development of the prefabricated home industry. The five key factors for the success of the prefabricated home industry include good quality, competitive prices, speed in installation, ease of customization, and effective promotion.

While from the results of internal analysis, we found several strengths of the company including good marketing channels, support of parent companies that have been moving for a long time in the same industry, production lines that allow for product customization, to a work culture that continues to promote innovation. Although there are still some weaknesses such as expensive product prices, long lead times, and digital marketing that has not been managed properly, the company can still do several alternative strategies to be able to continue to survive in the prefabricated house construction industry.

Two strategies that have the potential to be carried out by the company are the Quality of life Strategy, which is targeting early adopter public figures to show the impression of luxury and quality in prefabricated houses, supported by competitive advantages related to environmentally friendly buildings and promoted by maximizing digital marketing. This strategy targets massive awareness in the community, provides education, while creating a promotion system that maximizes digital marketing potential.

For the second strategy, companies can implement Home for everybody. Namely selling prefabricated houses by utilizing the support of the parent company to create complementary products. The target market is not as big as the first strategy, but it still carries product quality, which is supported through cooperation with banks or financial service providers to make the price of the product affordable. So that the use of prefabricated houses is not constrained later, then Woodlam Indonesia also needs to work with the government to formulate regulations related to the method of constructing prefabricated houses.

Based on the analysis of priorities that have been done, the authors suggest PT. Woodlam Indonesia Abadi to carry out the first strategy, namely the Quality of life strategy. In this strategy, the company is more concerned with public awareness of development using the prefabrication method. With this awareness, it is hoped that the stigma of poor prefabricated houses will be suppressed, and the community can begin to accept the presence of prefabricated houses in Indonesia. Awareness that is well built is expected to increase sales and accelerate the development of the company.

Based on the research that has been done, the academic suggestions that researchers can submit to be considered for further research are:

- In this research, researchers only focus on strategies that companies should carry out in developing prefabricated home business strategies. In conducting the analysis, researchers found that very few references were found about specific industry conditions because the industry was still new. It is hoped that, for further research, discussions can be made about external aspects that affect industrial development, such as factors that influence consumers in the purchase of prefabricated houses or about the key factors for the success of the prefabricated home industry.

- In this study, researchers also only limited to the formulation of strategies. For further research, it can be developed to the steps of implementing concrete strategies as well as monitoring and evaluating related strategies.

\section{REFERENCES}

[1] C. Preece, L.S. Pheng, R. Padfield and Papargyropoulou, "Developing and Marketing Sustainable Construction services," in Management \& Innovation for a Sustainable Built Environment CIB International Conference, Amsterdam, pp. 20-23, June 2011.

[2] Bank Indonesia, "Asesmen Sektoral Semester I-2018," Kategori Lapangan Usaha Konstruksi, 2018.

[3] S. Mostafa, N. Chileshe, J. Dumrak, and J. Zuo, "Offsite Manufacturing in Developing Countries: Current Situation and Opportunities," in International Conference on Engineering, Project, and Production Managemen, South Africa, November 2014.

[4] F.J. Lizana, J.A.J. Serrano, S.A. Vilches, P.A. Barrios, H.M. Molina "Life Cycle Assessment and Prefabrication. Valuation of the Environmental Performance in Different Industrialized Systems in the Building Sector," in II International and IV National Congress on Sustainable Construction and Eco Efficient Solutions, Chapter V, 2015.

[5] R.G. Putra, and D. Susanto, "Prefabricated house in real estate business development in Jabodetabek," in IOP Conference Series: Earth and Environmental Science, 2017.

[6] P. Bell, "Kiwi prefab: Prefabricated Housing in New Zealand: an Historical and Contemporary Overview with Recommendations for the Future," Thesis, Victoria University of Wellington, 2009.

[7] A. Hashemi, "Offsite Manufacturing: A Survey on the Current Status and Risks of Offsite Construction in Iran," in Journal of Civil Engineering and Architecture 9, pp. 141-152, 2015.

[8] Lu. Na, "Investigation of the Designers' and General Contractors' Perceptions of Offsite Construction Techniques in the United States Construction Industry," Dissertations, Clemson University, 2007,

[9] J. Garrison and A. Tweedie, "Modular Architecture Manual. Kullman Buildings Corporation," 2008.

[10] Gabe, T. Rossa and G. Amunisianto, "A Luxurious Prefabricated House: A Different Way of Understanding Prefabication Housing," in The 15th International Conference on QiR, 2017.

[11] A. Shahi, "Prefabricated Housing and LEED," in Theses and dissertations, Ryerson University. Paper 1788, 2012.

[12] C. Ngoenchuklin, "Feasibility of Implementing Prefabricated US Products and Methods for Residential Construction in Thailand," Thesis, Georgia Institute of Technology, 2014. 
[13] BCI Asia, "Construction, Bringing The Building and Design Industry to You," December edition, Issue 11, 2018.

[14] R. Berger, "Prefabricated Housing Market in Central and Northern Europe - Overview of Market Trends and Development," Study Extract, Munich, 2018.

[15] F.R. David, and F.R. David, "A Competitive Advantage Approach, Concepts and Cases, sixteenth edition," New Jersey: Pearson Prentice Hall-International, 2016.
[16] M.E. Porter, "Competitive Strategy, Techniques for Analyzing Industries and Competitors," New York: The Free Press, 1980.

[17] R.M. Grant, Contemporary Strategy Analysis, seventh edition, West Sussex: John Wiley \& Sons Ltd, 2010.

[18] H. Weihrich, "The TOWS Matrix: A Tool for Situational Analysis," Long Range Planning, Vol. 15, no. 2, 1982. 